\title{
ANALISIS PERUBAHAN GARIS PANTAI DESA RUTONG KOTA AMBON
}

\author{
Jesica D. Wattimena, Mansye Ronal Ayal \\ Program Studi Teknik Sipil, Fakultas Teknik, Universitas Pattimura \\ Jl. Ir. M. Putuhena, Kampus Poka, Ambon
}

\begin{abstract}
ABSTRAK
Ambon sebagai ibukota Provinsi Maluku merupakan Daerah Kepulauan yang mana sebagian besar desanya berada pada Daerah pesisir pantai. Hal ini membuat timbulnya berbagai permasalahan pantai. Pantai Desa Rutong Kecamatan Leitmur Selatan Kota Ambon merupakan salah satu daerah yang sering mendapat serangan gelombang dan mengakibatkan kerusakan yang cukup parah. Berdasarkan informasi dan tinjauan yang dilakukan, jenis pantai pada Desa Rutong ialah pantai pasir (Sandy Beach). Kondisi ini menyebabkan sejumlah besar material (Pasir) terbawa akibat gelombang angin dan pasang tertinggi sehingga terjadi erosi yang mengakibatkan adanya perubahan posisi garis pantai. Penelitian ini dilakukan dengan observasi dan pengamatan selama 15 hari di pantai Desa Rutong Kota Ambon. Melalui penelitian ini diperoleh besarnya perubahan garis pantai dengan menggunakan metode perhitungan CERC (Coastal Engineering Research Center) yaitu dengan membagi panjang garis pantai menjadi 50 pias untuk memprediksi perubahan garis pantai untuk 5 tahun dan 10 tahun ke depan. Dari analisis data tersebut diperoleh hasil bahwa Desa Rutong mengalami kemunduran garis pantai pada 5 tahun sebesar $-6,63 \mathrm{~m}$ di mana erosi terjadi pada pias 12 dan pada 10 tahun sebesar $16,04 \mathrm{~m}$ di mana erosi terjadi pada pias 0 .
\end{abstract}

Kata Kunci: garis pantai, pias.

\begin{abstract}
Ambon as the capital of Maluku Province is an archipelago area where most of the villages are in the coastal areas. This has led to various coastal problems. The coast of Rutong Village, South Leitmur Subdistrict, Ambon City is one of the areas that often gets wave attacks and causes considerable damage. Based on information and reviews conducted, the type of beach in Rutong Village is the sand beach (Sandy Beach). This condition causes a large amount of material (sand) to be carried away due to wind waves and the highest tides resulting in erosion resulting in changes in the position of the shoreline. This research was conducted by observation and observation for 15 days on the coast of Rutong Village, Ambon City. Through this study, the magnitude of the change in coastline using the CERC (Coastal Engineering Research Center) calculation method is to divide the coastline length into 50 pias to predict shoreline changes for the next 5 years and 10 years From the analysis of the data it was found that Rutong Village experienced a coastline decline of 5 years at $-6.63 \mathrm{~m}$ where erosion occurred in pias 12 and 10 years at $16.04 \mathrm{~m}$ where erosion occurred in pias 0.
\end{abstract}

Keywords: coastline, pias.

\section{PENDAHULUAN}

Negara Indonesia merupakan Negara kepulauan yang terdiri dari 17.000 buah pulau yang memiliki garis pantai terpanjang kedua di dunia setelah Kanada, yaitu sepanjang $81.000 \mathrm{~km}$. Lingkungan pantai merupakan suatu wilayah yang selalu mengalami perubahan. Perubahan lingkungan pantai dapat terjadi secara lambat hingga cepat, tergantung dari faktor-faktor yang mempengaruhinya. Oleh karena itu, kawasan pantai 
merupakan satu kawasan yang sangat dinamik begitu pula dengan garis pantainya. (Triatmodjo, 1999).

Berstatus sebagai Ibu Kota Provinsi Maluku Kota Ambon merupakan Daerah Kepulauan yang mana sebagian besar desanya berada pada Daerah pesisir pantai. Hal ini membuat timbulnya berbagai permasalahan pantai. Pantai Desa Rutong Kecamatan Leitmur Selatan Kota Ambon merupakan salah satu daerah yang sering mendapat serangan gelombang dan mengakibatkan kerusakan yang cukup parah.

Berdasarkan informasi dan tinjauan yang dilakukan, jenis pantai pada Desa Rutong ialah pantai pasir (Sandy Beach). Kondisi ini menyebabkan sejumlah besar material (Pasir) terbawa akibat gelombang angin dan pasang tertinggi sehingga terjadi erosi. Jika kondisi ini berlangsung terus-menerus maka akan menyebabkan masalah di daerah pantai. Masalah yang mendasar adalah masalah perubahan garis pantai (Shoreline Changes) yang nantinya akan jauh lebih parah dari kondisi saat ini, dimana daratan akn menjadi sempit.

Faktor penyebab terjadinya perubahan garis pantai ialah faktor alami yang berasal dari pengaruh proses-proses hidro-oseanografi yang terjadi di laut seperti hempasan gelombang, variasi pasang surut, serta perubahan iklim. Faktor ini berlangsung secara terus menerus sehingga wilayah pantai akan mengalami tekanan. (Triatmodjo, 1999).

Agar lebih terarah penulisan ini maka, beberapa hal perlu dibatasi antara lain :

1. Lokasi Penelitian hanya pada lokasi pesisir pantai Desa Rutong

2. Faktor yang mempengaruhi perubahan garis pantai yang akan ditinjau adalah yang diakibatkan oleh gelombang

3. Penelitian ini hanya menganalisis perubahan garis pantai tanpa dilakukan pemodelan atau perencanaan fasilitas pantai (Bangunan Pelindung Pantai)

4. Memprediksi gelombang berdasarkan data angin.

Alur penelitian ini dapat dilihat pada Gambar 1 di bawah ini. 


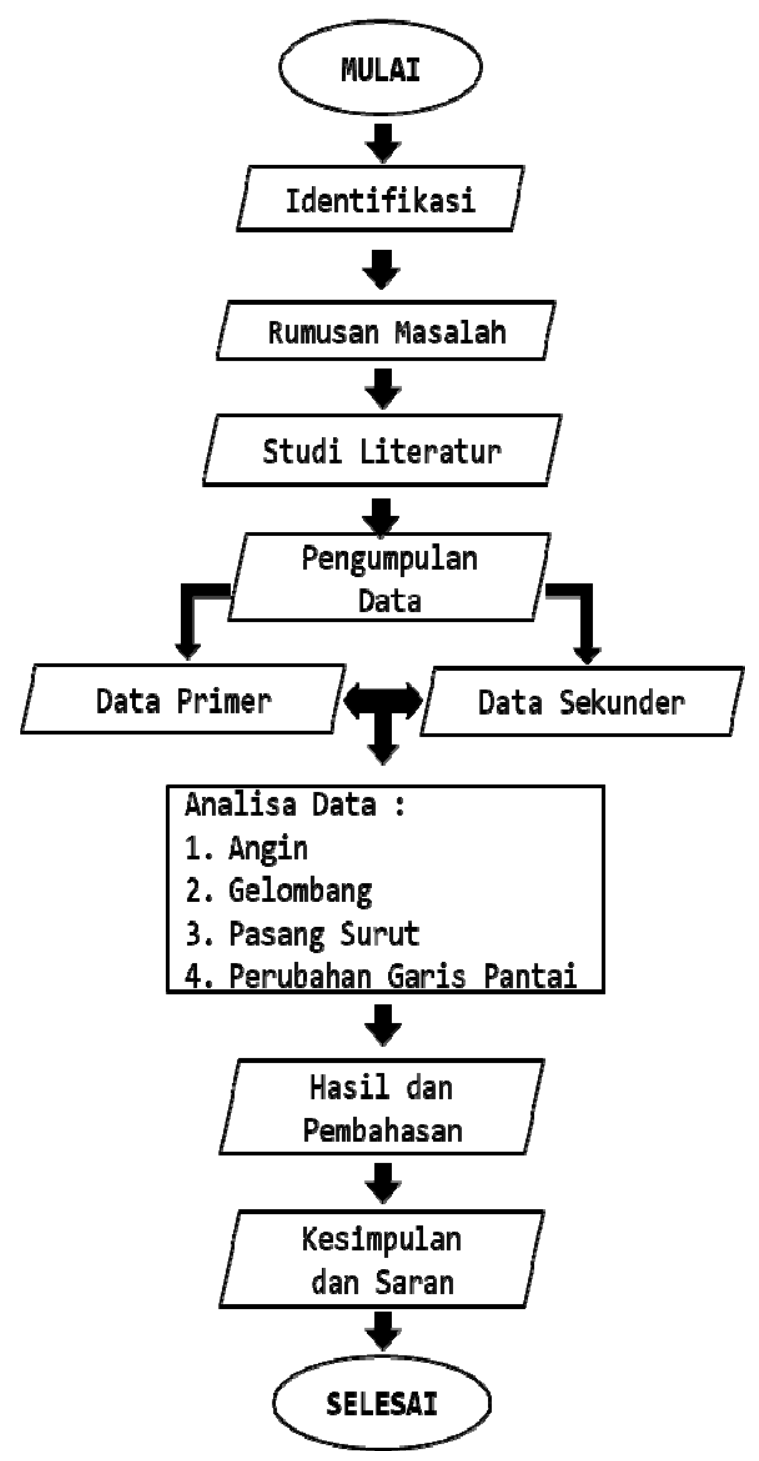

Gambar 1. Bagan alur penelitian

\section{KAJIAN TEORI}

\subsection{Pantai}

Pantai adalah jalur yang merupakan batas antara darat dan laut, diukur pada saat pasang tertinggi dan surut terendah, dipengaruhi oleh fisik laut dan sosial ekonomi bahari, sedangkan kearah darat dibatasi oleh proses alami dan kegiatan manusia di lingkungan darat (Triatmodjo, 1999). Penjelasan mengenai defenisi daerah pantai dapat dilihat dalam Gambar 2 berikut: 


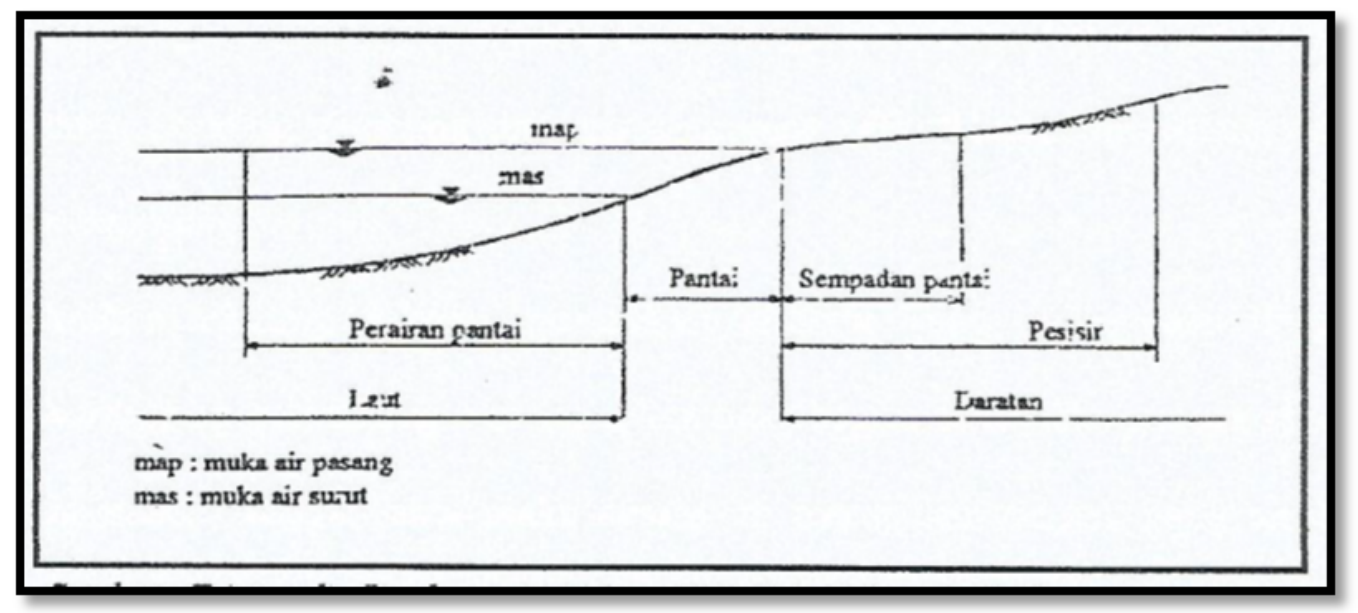

Gambar 2. Definisi dan batasan pantai

Sumber : Triatmodjo,1999, (Hal 2)

a. Pantai adalah daerah di tepi perairan yang dipengaruhi oleh surut terendah dengan pasang tertinggi.

b. Daerah lautan adalah daerah yang terletak di atas dan di bawah permukaan laut di mulai dari sisi laut pada garis surut terendah, termasuk dasar laut dan bagian bumi dibawahnya.

c. Pesisir adalah daerah darat di tepi laut yang masih mendapatkan pengaruh laut.

d. Daerah daratan adalah daerah yang terletak diatas dan di bawah permukaan daratan dimulai dari batas garis pasang tertinggi.

e. Sepadan Pantai adalah daerah sepanjang panati yang diperuntukkan bagi pengamanan dan pelestarian pantai.

Menurut Triatmodjo (1999), morfologi pantai dan dasar laut dekat pantai akibat pengaruh terhadap gelombang dibagi menjadi empat kelompok yang berurutan dari darat ke laut sebagai berikut:

1. Backshore merupakan bagian dari pantai yang tidak terendam air laut kecuali bila terjadi gelombang badai

2. Foreshore merupakan bagian pantai yang dibatasi oleh beach face atau muka pantai pada saat surut terendah hingga uprush pada saat air pasang tinggi.

3. Inshore merupakan daerah dimana terjadinya gelombang pecah, memanjang dari surut terrendah sampai ke garis gelombang pecah. 
4. Offshore yaitu bagian laut yang terjauh dari pantai (lepas pantai), yaitu daerah dari garis gelombang pecah ke arah laut..

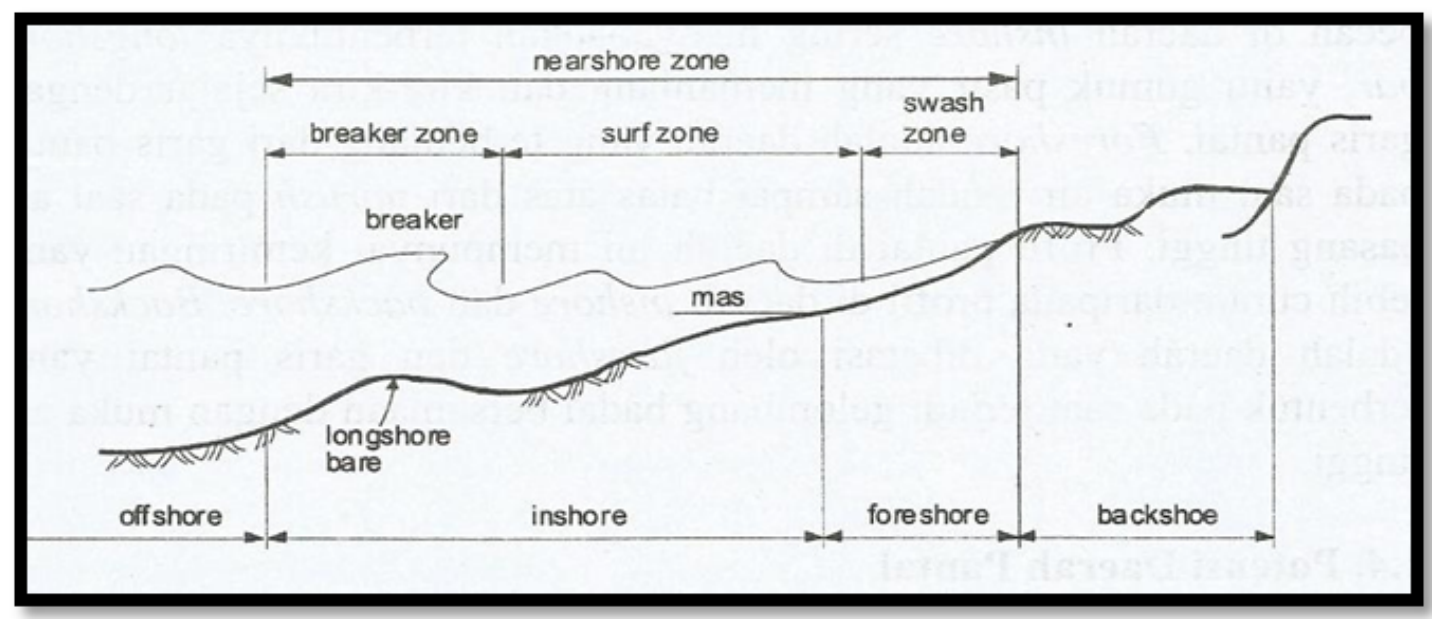

Gambar 3. Karakteristik Gelombang di Daerah Pantai

\section{Sumber :Triatmodjo,1999, (Hal 3}

Tipe pantai sangat berpengaruh terhadap kemudahan terjadinya pantai. Berikut ini diuraikan tentang tipe-tipe pantai yang ada di Indonesia berdasarkan tipe paparan (shelf) dan perairan (Praktikto,1997):

1. Pantai Paparan, merupakan pantai dengan proses pengendapan yang dominan

2. Pantai Samudra, merupakan pantai di mana proses erosi lebih dominan.

3. Pantai Pulau, merupakan pantai yang mengelilingi pulau kecil yang dibentuk oleh endapan sungai, batu gamping, endapan gunung berapi atau endapan lainnya.

\subsection{Karakteristik Gelombang}

Gelombang adalah salah satu bentuk energi yang dapat membentuk pantai, menimbulkan arus dan trasnspor sedimen. Secara umum bentuk gelombang di alam sangatlah kompleks dan sulit digambarkan secara matematis karena ketidaklinieran, tiga dimensi dan mempunyai bentuk yang random dengan pengertian suatu deret gelombang mempunyai tinggi dan periode yang berbeda. (Triatmodjo, 1999).

Teori gelombang airy merupakan salah satu teori untuk menggambarkan gelombang di alam. Teori ini juga disebut teori gelombang linier atau teori gelombang amplitude kecil. Selain sederhana dan mudah dipahami teori ini juga memberikan model 
persamaan penting dalam menentukan properti gelombang pada permukaan. (Triatmodjo, 1999).

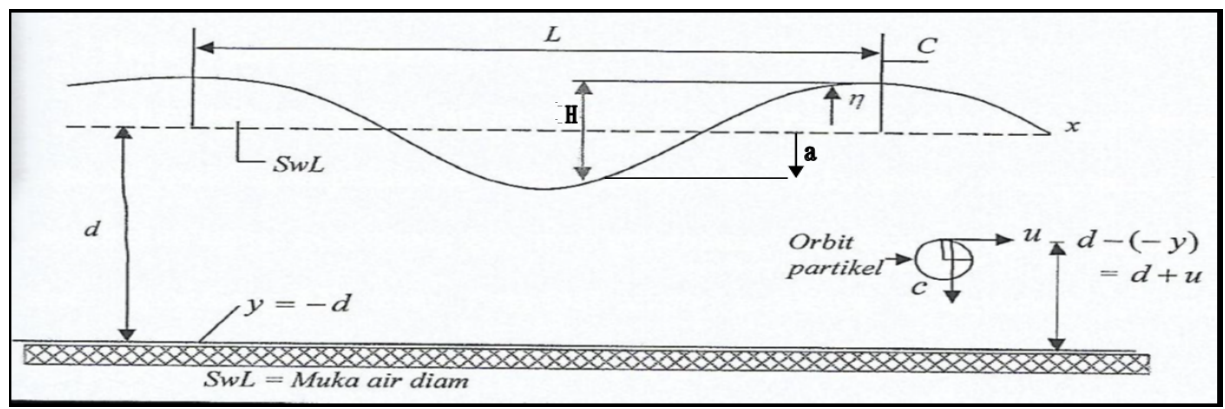

\section{Gambar 4. Defenisi Gelombang \\ Sumber :Triatmodjo,1999,(Hal.14)}

Keterangan :

d : jarak antara muka air merata dan dasar laut.

$\eta(x, t) \quad$ : Fluktuasi muka air terhadap muka air diam.

a : : Amplitudo gelombang

$H \quad$ : Tinggi Gelombang

$T \quad$ : Periode gelombang yaitu interval waktu yang diperlukan oleh partikel air untuk kembali pada kedudukan yang sama dengan kedudukan sebelumnya

L : Panjang gelombang yaitu jarak antara dua puncak gelombang yang Berurutan.

C $\quad$ : Kecepatan rambat gelombang $=\mathrm{L} / \mathrm{T}$

$K \quad$ : Angka gelombang $=2 \pi / \mathrm{L}$.

$\sigma \quad$ : Frekuensi gelombang

Berdasarkan kedalaman relatif, yaitu perbandingan antara kedalaman air d dan panjang gelombang L, (d/L), gelombang diklasifikasikan menjadi tiga macam yaitu: (Triatmodjo, 2011).

1. Gelombang di laut dangkal jika $\mathrm{d} / \mathrm{L} \leq 1 / 20$

2. Gelombang dilaut Transisi jika $1 / 20 \leq \mathrm{d} / \mathrm{L} \leq 1 / 2$

3. Gelombang dilaut dalam jika d/L $>1 / 2$

Untuk menentukan tinggi gelombang signifikan (Hs), periode gelombang (Ts), diperoleh dengan cara memasukan nilai wind stress $\left(\mathrm{U}_{\mathrm{A}}\right)$, panjang fetch effektif $\left(\mathrm{F}_{\text {eff }}\right)$ kedalam persamaan:

$$
\begin{array}{ll}
\mathrm{U}_{\mathrm{A}} & =0,71 \cdot \mathrm{U}^{1,23} \mathrm{dt} \\
\mathrm{H}_{\mathrm{S}} & =5,112 \times 10^{-4} \cdot \mathrm{U}_{\mathrm{A}} \cdot \mathrm{F}^{1 / 2}(\mathrm{~m})
\end{array}
$$


Ts $\quad=6,23 \times 10^{-2}\left(\mathrm{U}_{\mathrm{A}} \cdot \mathrm{F}\right)^{1 / 3}(\mathrm{dtk})$

\subsection{Gelombang Pecah}

Merupakan gelombang yang menjalar dari tempat yang dalam menuju ke tempat yang makin lama makin dangkal, maka pada suatu lokasi tertentu gelombang tersebut akan pecah. Karena mengalami perubahan bentuk dengan adanya pengaruh kedalaman laut. Pengaruh kedalaman laut mulai terasa lebih kecil dari setengah kali panjang gelombang. Di laut dalam profil gelombang adalah semakin tajam dan lemah gelombang semakin datar. Selain itu kecepatan dan panjang gelombang berkurang secara berangsurangsur sementara tinggi gelombang bertambah. Gelombang dapat dibedakan menjadi Spilling, plunging atau surging. Spilling bisanya terjadi apabila gelombang dengan kemiringan kecil menuju ke pantai yang datar. (kemiringan kecil).

Gelombang mulai pecah pada jarak yang cukup jauh dari pantai dan pecahnya terjadi berangsur-angsur. Buih terjadi pada puncak gelombang selama mengalami pecah dan meninggalkan suatu lapis buih pada jarak yang cukup jauh. Plunging terjadi apabila kemiringan gelombang dan dasar bertambah, gelombang akan pecah dan puncak gelombang akan memutar dengan massa air dan puncak gelombang terjun ke depan. Energi gelombang pecah dihancurkan dalam tuberlensi. Surging terjadi pada pantai dengan kemiringan yang sangat besar seperti yang terjadi pada pantai berkarang. Daerah gelombang pecah sangat sempit dan sebagian besar energi dipantul lagi ke laut. Sebelum puncak gelombang terjun dasar gelombang sudah pecah. (Triatmodjo,1999)

Kondisi gelombang pecah tergantung pada kemiringan dasar pantai dan kecuraman gelombang, sehingga tinggi gelombang pecah dapat dihitung dengan persamaan :

$$
\frac{H_{k}}{H^{\prime} 0}=\frac{1}{3,2\left(H^{r} \alpha /{ }_{\mathrm{HiO}}\right)^{1 / 8}}
$$

Kedalaman air dimana terjadi gelombang pecah adalah :

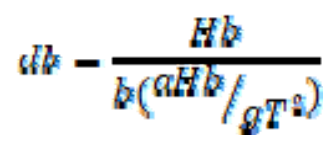

Dimana:

$$
\begin{array}{ll}
\mathrm{H}_{\mathrm{b}} & \text { : tinggi gelombang pecah } \\
\mathrm{H}_{0} & \text { : tinggi laut dalam ekivalen } \\
\mathrm{d}_{\mathrm{b}} & : \text { kedalaman air pada saat gelombang pecah } \\
\mathrm{g} & : \text { percepatan gravitasi } \\
\mathrm{T} & \text { : periode gelombang }
\end{array}
$$


Sudut datang gelombang pecah dihitung berdasarkan analisis refraksi pada kedalaman dimana terjadi gelombang pecah. Gambar 5 adalah grafik yang dibuat Goda yang memberikan hubungan antara $\mathrm{Hb} / \mathrm{H}^{\prime} 0$ dan H'0 / gT2 untuk berbagai kemiringan dasar pantai. Sedangkan Gambar 6 adalah grafik hubungan antara db / H'0 dan Hb / gT2.

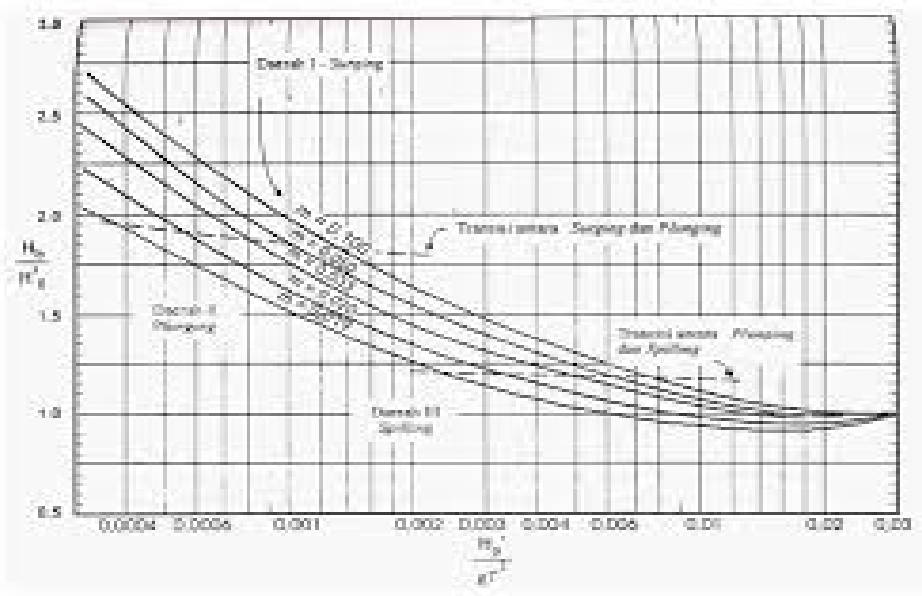

Gambar 5. Grafik Penentuan tinggi gelombang pecah (SPM,1999) Sumber: Triatmodjo,1999 (Hal.51)



Gambar 6. Grafik Penentuan kedalaman gelombang pecah (SPM,1999) Sumber: Triatmodjo,1999,(Hal.51)

\subsection{Fetch}

Fetch merupakan daerah dimana kecepatan dan arah angin adalah konstan. Jika perubahan arah angin tidak lebih dari $15^{\circ}$, maka masih dianggap konstan. Sama halnya 
dengan kecepatan angin yang masih dianggap konstan jika perubahannya tidak lebih dari 5 knot (2,5 m/dtk) terhadap kecepatan rerata. (Triatmodjo, 1999).

Fetch dapat diartikan sebagai panjang daerah pembangkit gelombang pada arah datangnya angin. Waktu yang diperlukan untuk terbentuknya gelombang dibatasi oleh panjang fetch karena pengaruh angin. Sehinnga mempengaruhi waktu untuk mentrasfer energi angin ke gelombang. Fetch juga berpengaruh pada periode dan tinggi gelombang yang dibangkitkan. Gelombang dengan periode panjang akan terjadi, namun umumnya hanya berkisar antara 10 dan $15 \mathrm{dtk}$. Jika bentuk daerah pembangkit tidak teratur, maka untuk keperluan peramalan gelombang perlu ditentukan fetch efektif $\left(\mathrm{F}_{\text {eff }}\right)$ dengan persamaan berikut (Triatmodjo, 1999).

$$
E_{\text {fff }} \frac{\sin _{t} x_{t} \cos \alpha_{t}}{\sum \cos \alpha_{t}}
$$

Dimana:

$$
\begin{array}{ll}
\text { Feff } & : \text { Fetch } \text { effektif } \\
\mathrm{Xi} & \text { : panjang fetch pada arah yang ditinjau } \\
\alpha & \text { : sudut antara jalur fetch yang ditinjau dengan arah mata angin. }
\end{array}
$$

\subsection{Pemodelan Perubahan Garis Pantai}

Pengaruh Gelombang, arus dan pasang surut terhadap pantai mengakibatkan perubahan bentuk pantai. Perubahan garis pantai atau sering disebut evolusi garis pantai terjadi pada skala detik sampai jutaan tahun dan mengakibatkan terjadinnya erosi ataupun akresi. Terjadinya erosi atau akresi pada suatu pantai tergantung pada keadaan angkutan sedimen di daerah tersebut. (Triatmodjo,1999)

Pembuatan model matamatik yang berdasar pada imbangan sedimen pantai dapat memprediksi perubahan garis pantai pada lokasi yang ditinjau. Permodelan perubahan garis pantai memakai metode CERC (Coastal Engineering Research Center) yaitu metode untuk memprediksi dan menghitung daerah yang mengalami erosi dan sedimentasi karena adanya transport sedimen akibat gelombang yang sampai di pantai dengan metode ini kita dapat mengetahui transport sedimen total. CERC tidak memperhitungkan sifat-sifat sedimen dasar, rumus tersebut diturunkan untuk pantai yang terdiri dari pasir agak seragam. (Yuwono, 1982).

Analisis Perubahan Garis Pantai Desa Rutong Kota Ambon 
Model perubahan garis pantai ini berdasarkan hukum kontinuitas sedimen sebagai berikut:

$$
\frac{g y}{2 x}=-\frac{1}{d} \frac{g Q}{2 x}
$$

Dimana:

y $\quad$ : Jarak anatara garis pantai dan garis referensi

Q : : Transport sedimen sepanjang pantai

t : Waktu

$\mathrm{x} \quad$ : Absis searah garis pantai.

d : kedalaman air yang tergantunng pada profil pantai.

Permodelan perubahan garis pantai dilakukan dengan cara membagi pantai menjadi sejumlah pias (sel) dan interval waktu dalam sejumlah langkah waktu seperti pada Gambar 7 dimana pada gambar ini menjelaskan bahwa transport sedimen akan mengalir dari sel i ke $\mathrm{i}+1$, dimana setiap sel mempunyai lebar $\Delta \mathrm{x}$ yang seragam dan masing-masing memiliki panjang $\mathrm{Yi}-1, \mathrm{Yi}, \mathrm{Yi}+1 \ldots \ldots \ldots . . . \mathrm{Yn}$ terhadap suatu garis patokan tertentu. Volume sel garis pantai, $\Delta V \mathrm{~V}$ akibat Littoral Drift dari sel i ke sel i+1, maka $\Delta V i$ dapat dihitung dengan menggunakaan rumus berikut:

\section{$\Delta V_{t}-\left(Q_{i-1}-Q_{t} \pm Q_{n}\right) \Delta t$}

Dimana:

$$
\begin{array}{ll}
\Delta \mathrm{V}_{\mathrm{i}} & : \text { sel garis pantai } \\
\Delta \mathrm{t} & \text { : waktu yang dilewati selama perubahan garis pantai } \\
\mathrm{Qi} & : \text { Littoral Drift sel ke-i } \\
\mathrm{Qr} & \text { : batas keseimbangan Littoral Drift } \\
\mathrm{Q}_{\mathrm{i}-1} & : \text { Littoral Drift sel ke i-1. }
\end{array}
$$

Transport sedimen sejajar pantai tergantung pada sudut datangnya gelombang pecah $(\alpha b)$. perubahan garis pantai mengakibatkan terjadinya perubahan sudut gelombang pecah dari satu sel ke sel yang lain. Pada gambar 2.6 sudut $\alpha 1$ merupakan sudut yang terbentuk oleh garis pantai sejajar sumbu $\mathrm{x}$, anatara sel I dan sel $i+1$ sesuai dengan persamaan berikut (Triatmodjo,1999):

\section{$\operatorname{Tan} \alpha_{i}=\frac{g_{i}-\nabla_{i+n}}{\Delta x}$}




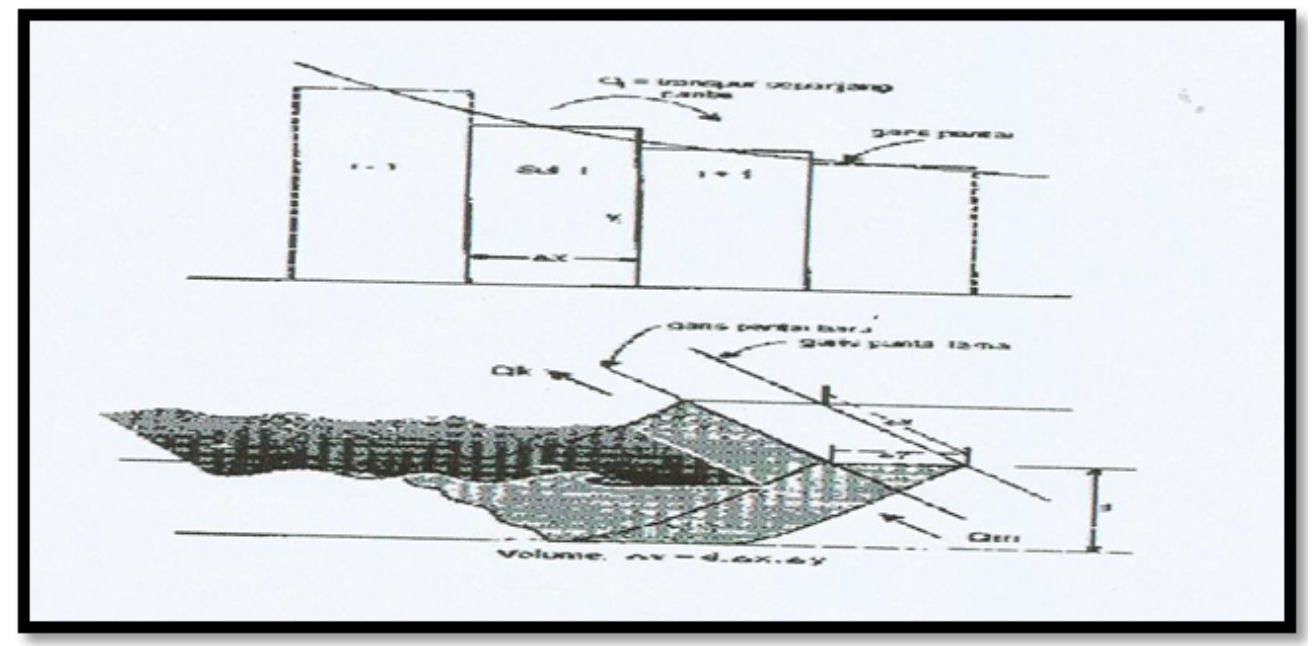

Gambar 7. Pembagian garis pantai dalam beberapa pias

Sumber: Triatmodjo,1999,(Hal.192)

Jika sudut gelombang datang membentuk sudut $\alpha 0$ dengan arah sumbu $\mathrm{x}$, sesuai dengan Gambar 8 maka sudut gelombang pecah terhadap garis pantai adalah $\alpha \mathrm{b}=\alpha \mathrm{i} \pm \alpha 0$. Berikut ini persamaan yang digunkan untuk menghitung sudut gelombang pecah:

$$
\operatorname{Tan} \alpha_{b}=\tan \left(\alpha_{1} \pm \alpha_{Q}\right) \frac{\tan \left(\alpha_{4}+\kappa_{\alpha}\right)}{\operatorname{1.\operatorname {man}} \alpha_{n} \tan \kappa_{m}}
$$



Gambar 8 Hubungan Antara $\alpha_{0}, \alpha_{1}, \alpha_{\mathrm{b}}$

(Sumber : Triatmodjo,1999,(Hal.193) 
Berikut ini langkah model perubahan garis pantai:

1. Menentukan bentuk garis pantai awal $\left(\mathrm{Y}_{1}, \mathrm{Y}_{2}, \mathrm{Y}_{3}, \ldots \ldots \mathrm{Y}_{\mathrm{n}}\right)$

2. Membagi garis pantai menjadi beberapa bagian pias/sel $(\Delta \mathrm{x})$

3. Menentukan sumber sedimen dan sedimen yang hilang pada seluruh pias $\left(\mathrm{Q}_{\mathrm{e}}\right)$

4. Menghitung perubahan garis pantai untuk setiap langkah waktu $(\Delta t)$

\subsection{Refraksi Gelombang}

Refraksi terjadi karena adanya pengaruh perubahan kedalaman laut pada daerah dimana air lebih besar dari pada panjang gelombang yaitu di laut dalam, gelombang menjalar tanpa dipengaruhi oleh dasar laut. Tetapi pada laut transisi dan dangkal dasar laut akan mempengruhi gelombang. Selama perambatan gelombang dari perairan laut dalam ke perairan laut dangkal, maka gelombang akan mengalami refraksi yaitu terjadi perubahan karakteristik gelombang disebabkan oleh perubahan kedalaman air. Studi refraksi dilakukan secara analisis dengan menganggap bahwa kontur dasar laut yang dilintasi oleh setiap garis ortogonal gelombang untuk berbagai arah gelombang adalah sejajar. (Triatmodjo,1999).

Seperti terlihat pada Gambar 9jarak antara orthogonal di laut dalam dan di titik 1 adalah $b_{0}$ dan $b$. apabila kontur dasar laut adalah lurus dan sejajar maka $\mathrm{x}$ di titik 0 dan 1 adalah sama sehingga: $x=\frac{b_{8}}{\operatorname{sef} \kappa_{\mathrm{n}}}=\frac{b}{\operatorname{sog} \kappa}$

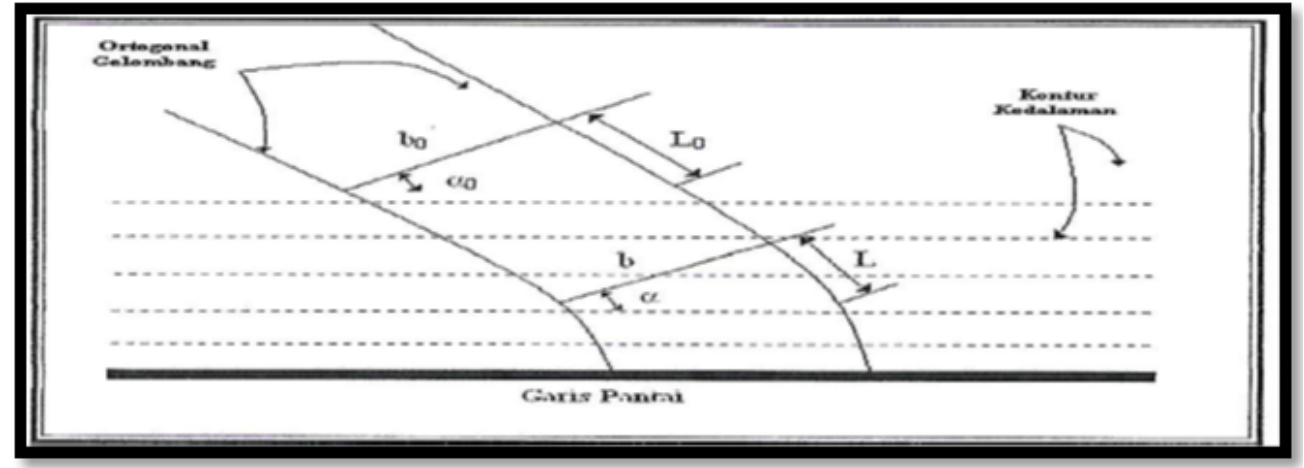

Gambar 9. Refraksi Gelombang pada kontur lurus dan sejajar Sumber: Triatmodjo,1999,(Hal.69)

Koefisien Refraksi adalah:

$$
K_{p}=\left(\frac{\cos \alpha \theta}{\sin \alpha}\right)^{\frac{1}{2}}
$$


Karena adanya perubahan kedalaman maka cepat rambat dan panjang gelombang berkurang dari $\mathrm{C}_{0}$ dan $\mathrm{L}_{0}$ menjadi $\mathrm{C}_{1}$ dan $\mathrm{L}_{1}$. Sehingga diperoleh:

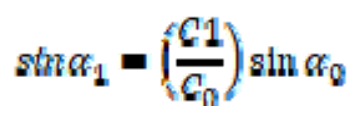

Dimana:

$\mathrm{Kr} \quad$ : Koef. Refraksi

$\alpha \quad$ : sudut antara garis puncak gelombang dan garis kontur dasar laut di titik yang ditinjau.

$\alpha_{0} \quad$ : sudut antara garis puncak gelombang di laut dalam dan garis pantai

C : Kecepatan rambat Gelombang $(\mathrm{m} / \mathrm{s})$

$\mathrm{C}_{0} \quad$ : Kecepatan rambat Gelombang di laut dalam $(\mathrm{m} / \mathrm{s})$

\section{DATA DAN ANALISIS}

\subsection{Pasang surut}

Untuk memprediksi besarnya perubahan garis pantai salah satu data penting yang diperlukan adalah data pasang surut air laut. Data tersebut diperoleh dari pengamatan selama 15 hari di Desa Rutong Kota Ambon dan ditunjukkan pada tabel di bawah ini:

Tabel 1. Pasang surut air laut

\begin{tabular}{|c|c|c|c|c|c|c|c|c|c|c|c|c|c|c|c|c|c|c|c|c|c|c|c|c|c|}
\hline \multirow{2}{*}{\multicolumn{2}{|c|}{\begin{tabular}{c|c|} 
No & Tangsa \\
\end{tabular}}} & \multicolumn{24}{|c|}{ JAM } \\
\hline & & 1 & 2 & 3 & 4 & 5 & 6 & 7 & 8 & 9 & 10 & 11 & 12 & 13 & 14 & 15 & 16 & 17 & 18 & 19 & 20 & 21 & 22 & 23 & 24 \\
\hline 1 & \begin{tabular}{|c|}
$\begin{array}{c}01 / 04 / \\
2018\end{array}$ \\
\end{tabular} & 1,80 & 1,60 & 1,60 & 1,40 & 1,10 & 0,90 & 0,80 & 0,90 & 1,00 & 1,30 & 1,60 & 1,80 & 1,90 & 1,90 & 1,70 & $|1,40|$ & 1,10 & 0,80 & $0,60 \mid$ & 0,60 & 0,70 & 1,00 & 1,30 & 1,60 \\
\hline 2 & \begin{tabular}{|c|}
$02 / 04 /$ \\
2018 \\
\end{tabular} & 1,80 & $\mid 1,90$ & 1,80 & 1,60 & 1,30 & 1,10 & 0,90 & 0,80 & 0,90 & 1,20 & $|1,50|$ & 1,80 & $2,00 \mid$ & 2,00 & 1,90 & $|1,70|$ & $|1,30|$ & 0,90 & 0,60 & $0,40 \mid$ & 0,40 & 0,60 & 1,00 & 1,30 \\
\hline 3 & \begin{tabular}{|c|}
$3 / 04 /$ \\
2018 \\
\end{tabular} & 1,70 & 1,90 & 1,90 & 1,80 & 1,60 & 1,30 & 1,00 & 0,80 & 0,80 & 1,00 & 1,30 & 1,70 & 2,00 & 2,10 & 2,10 & 1,90 & 1,50 & 1,10 & 0,70 & 0,40 & 0,30 & 0,40 & 0,60 & 1,00 \\
\hline 4 & \begin{tabular}{|l|}
$04 / 04 /$ \\
2018 \\
\end{tabular} & 1,40 & $|1,80|$ & 1,90 & 1,90 & 1,80 & 1,50 & 1,20 & 0,90 & 0,80 & 0,90 & 1,20 & 1,50 & 1,90 & 2,10 & 2,20 & $2,10 \mid$ & 1,80 & 1,40 & 0,90 & 0,50 & 0,20 & 0,20 & 0,40 & 0,70 \\
\hline 5 & \begin{tabular}{|l|}
$55 / 04 /$ \\
2018 \\
\end{tabular} & 1,10 & .50 & 1,80 & 2,00 & 1,90 & 1,70 & 1,40 & 1,10 & 0,90 & 0,90 & 1,00 & 1,30 & 1,70 & 2,00 & 2,20 & $2,20 \mid$ & 2,00 & 1,70 & $1,20 \mid$ & 0,70 & $0,30 \mid$ & 0,10 & 0,20 & 0,40 \\
\hline 6 & \begin{tabular}{|c|}
$06 / 04 /$ \\
2018 \\
\end{tabular} & 0,80 & 1,20 & 1,60 & 1,90 & 1,90 & 1,80 & 1,60 & 1,30 & 1,00 & 0,90 & 0,90 & 1,10 & 1,50 & 1,80 & $2,10 \mid$ & $|2,20|$ & $2,20 \mid$ & 1,90 & 1,50 & 1,10 & $0,60 \mid$ & 0,30 & 0,20 & 0,20 \\
\hline 7 & \begin{tabular}{|c|}
$07 / 041$ \\
2018
\end{tabular} & 0,50 & $0,90 \mid$ & 1,30 & 1,70 & 1,80 & 1,90 & 1,70 & 1,50 & 1,20 & 1,00 & $0,90 \mid$ & 1,00 & $1,30 \mid$ & 1,60 & 1,90 & $2,10 \mid$ & $2,20 \mid$ & 2,10 & 1,80 & 1,40 & 1,00 & 0,60 & 0,30 & 0,20 \\
\hline 8 & $\begin{array}{c}08 / 04 / \\
2018 \\
\end{array}$ & 0,40 & $0,60 \mid$ & 1,00 & 1,40 & 1,70 & 1,80 & 1,80 & 1,70 & 1,50 & 1,20 & 1,10 & 1,00 & 1,10 & 1,30 & 1,60 & 1,90 & 2,10 & 2,10 & $2,00 \mid$ & 1,70 & 1,30 & 0,90 & 0,60 & 0,40 \\
\hline 9 & \begin{tabular}{|l|}
$99 / 04 /$ \\
2018 \\
\end{tabular} & 0,30 & 0,50 & 0,70 & 1,10 & 1,40 & 1,60 & 1,80 & $1,70 \mid$ & 1,60 & 1,40 & 1,20 & 1,10 & 1,10 & 1,20 & 1,40 & $|1,60|$ & $|1,80|$ & 1,90 & 2,00 & 1,80 & $1,60 \mid$ & 1,30 & 1,00 & 0,70 \\
\hline 10 & $\begin{array}{c}10 / 04 / \\
2018 \\
\end{array}$ & 0,50 & $0,50 \mid$ & 0,60 & 0,80 & 1,10 & 1,40 & 1,60 & 1,70 & 1,70 & 1,60 & 1,50 & 1,30 & 1,10 & 1,10 & 1,20 & $1,30 \mid$ & 1,50 & 1,70 & $|1,80|$ & 1,80 & 1,80 & 1,60 & 1,30 & 1,00 \\
\hline 11 & $\begin{array}{c}11 / 04 / \\
2018 \\
\end{array}$ & 0,80 & $|0,60|$ & 0,60 & 0,70 & 0,90 & 1,10 & 1,40 & 1,60 & 1,70 & 1,70 & 1,70 & 1,50 & $1,30 \mid$ & 1,10 & 1,10 & $|1,10|$ & $1,20 \mid$ & 1,40 & 1,50 & 1,70 & 1,80 & 1,70 & $1,60 \mid$ & $1,40 \mid$ \\
\hline 12 & \begin{tabular}{|c|}
$12 / 04 /$ \\
2018 \\
\end{tabular} & 1,10 & 0,90 & 0,70 & 0,70 & 0,70 & 0,90 & 1,20 & 1,40 & 1,60 & 1,80 & 1,80 & 1,70 & $1,50 \mid$ & 1,30 & 1,10 & $|1,00|$ & 1,00 & 1,00 & 1,20 & 1,40 & 1,60 & 1,70 & 1,70 & 1,70 \\
\hline 13 & \begin{tabular}{|c|}
$13 / 04 /$ \\
2018 \\
\end{tabular} & 1,50 & $|1,20|$ & 1,00 & 0,80 & 0,70 & 0,80 & 0,90 & 1,20 & 1,50 & 1,70 & 1,80 & 1,90 & 1,80 & 1,50 & 1,30 & $|1,00|$ & 0,80 & $0,80 \mid$ & $0,90 \mid$ & 1,10 & 1,30 & 1,50 & 1,70 & 1,80 \\
\hline 14 & $\begin{array}{c}14 / 04 / \\
2018\end{array}$ & 1,80 & 1,60 & 1,30 & 1,00 & 0,80 & 0,80 & 0,80 & 1,00 & 1,30 & 1,50 & 1,80 & 90 & 90 & 1,80 & 1,50 & 1,20 & 0,80 & 0,70 & $0,60 \mid$ & 0,70 & 1,00 & 1,20 & 1,50 & 1,80 \\
\hline 15 & \begin{tabular}{|l}
$15 / 04 !$ \\
2018 \\
\end{tabular} & 1,90 & 1,80 & 1,60 & 1,40 & 1,10 & 0,90 & 0,80 & 0,90 & 1,10 & 1,40 & 1,70 & 1,90 & 2,00 & 2,00 & 1,70 & $|1,40|$ & 1,00 & 0,70 & 0,50 & $0,50 \mid$ & 0,60 & 0,90 & 1,30 & 1,60 \\
\hline & 10 & & & & & & & & & & & 00 & 50 & 4, & & & & & & & & & & 14.7 & \\
\hline
\end{tabular}




\subsection{Angin}

Untuk menganalisa seberapa besar perubahan garis pantai yang terjadi pada lokasi penelitian maka dibutuhkan data angin harian yang diambil dari Badan Meteorologi Klimatologi dan Geofisika (BMKG) Stasiun Meteoriologi Klas II Pattimura Ambon selama 10 tahun terakhir (2008-2017) data ini kemudian di konversikan dalam delapan penjuru mata angin (Utara, Timur Laut, Timur, Tenggara, Selatan, Barat Daya, Barat, Barat Laut).

Tabel 2. Jumlah hari kejadian rata-rata angin Tahun 2008 - 2017

\begin{tabular}{ccccccccccc}
\hline \multicolumn{10}{c}{ Kec } & \multicolumn{10}{c}{ JUMLAH KEJADIAN ANGIN TAHUN 2008-2017 } \\
(Knot) & U & TL & T & TG & S & BD & B & BL & CALM & Jumlah \\
\hline $0-2$ & 40 & 2 & 2 & 7 & 5 & 6 & 2 & 11 & 17 & 92 \\
$3-5$ & 1273 & 48 & 28 & 370 & 323 & 289 & 34 & 743 & 97 & 3205 \\
$6-8$ & 73 & 0 & 6 & 141 & 64 & 26 & 1 & 30 & 0 & 341 \\
$9-11$ & 2 & 0 & 1 & 6 & 3 & 1 & 0 & 0 & 0 & 13 \\
$12-14$ & 1 & 0 & 0 & 1 & 0 & 0 & 0 & 0 & 0 & 2 \\
Jumlah & 1389 & 50 & 37 & 525 & 395 & 322 & 37 & 784 & 114 & 3653 \\
\hline
\end{tabular}

Dari data yang diperoleh pada Tabel 2 diatas perlihat dengan jelas bahwa jumlah hari berangin terbanyak selama 10 tahun (2008-2017) berasal dari arah Utara dengan jumlah 1339 hari atau 38,02 \% dan tersedikit ada pada posisi Barat dan Timur dengan jumlah angin 37 hari atau 1,01\%.

Tabel 3. Presentase Hari kejadian angin rata-rata Tahun 2008-2017

\begin{tabular}{ccccccccccc}
\hline \multicolumn{1}{c}{ PRESENTASE } & KEJADIAN ANGIN RATA-RATA TAHUN 2008-2017 & \\
Krah Angin (o) \\
(Knot) & U & TL & T & TG & S & BD & B & BL & CALM & Jumlah \\
\hline $0-2$ & 1,09 & 0,05 & 0,05 & 0,19 & 0,14 & 0,16 & 0,05 & 0,30 & 0,47 & 2,52 \\
$3-5$ & 34,85 & 1,31 & 0,77 & 10,13 & 8,84 & 7,91 & 0,93 & 20,34 & 2,66 & 87,74 \\
$6-8$ & 2,00 & 0 & 0,16 & 3,86 & 1,75 & 0,71 & 0,03 & 0,82 & 0 & 9,33 \\
$9-11$ & 0,05 & 0 & 0,03 & 0,16 & 0,08 & 0,03 & 0 & 0 & 0 & 0,36 \\
$12-14$ & 0,03 & 0 & 0 & 0,03 & 0 & 0 & 0 & 0 & 0 & 0,05 \\
Jumlah & 38,02 & 1,37 & 1,01 & 14,37 & 10,81 & 8,81 & 1,01 & 21,46 & 3,12 & 100 \\
\hline
\end{tabular}

Penarikan garis fetch untuk peramalaman gelombang pada lokasi penelitian ditentukan berdasarkan arah angin. Dilihat dari kedudukannya untuk meghitung panjang fetch Desa Rutong maka arah angin dominan yaitu Timur, tenggara dan Selatan. Berikut ini cara yang digunakan untuk menentukan panjang $f e t c h$ atau pembentukan gelombang : 
1. Menarik garis fetch pada setiap interval $3^{\circ}$

2. Panjang fetch yang dihitung mulai dari titik lokasi yang ditinjau sampai kedaratan diujungnya

3. Untuk panjang fetch efektif maka panjang garis fetch tiap arah dibagi dengan cosinus sudutnya.

Tabel 4. Perhitungan Fetch Efektif untuk Desa Rutong Arah Timur

\begin{tabular}{cccccc}
\hline \multirow{2}{*}{ No } & Sudut $\boldsymbol{\alpha}$ & Cos $\boldsymbol{\alpha}$ & Panjang Fetch (Xi) & Xi Cos $\boldsymbol{\alpha}$ \\
\hline 1 & 21 & 0,9336 & 4,5 & 36000 & 33608,90 \\
2 & 18 & 0,9511 & 5 & 40000 & 38042,26 \\
3 & 15 & 0,9659 & 5,5 & 44000 & 42500,74 \\
4 & 12 & 0,9781 & 19,5 & 156000 & 152591,03 \\
5 & 9 & 0,9877 & 5,5 & 44000 & 43458,29 \\
6 & 6 & 0,9945 & 6 & 48000 & 47737,05 \\
7 & 3 & 0,9986 & 25 & 200000 & 199725,91 \\
8 & 0 & 1,0000 & 27 & 216000 & 216000,00 \\
9 & 3 & 0,9986 & 30 & 240000 & 239671,09 \\
10 & 6 & 0,9945 & 35 & 280000 & 278466,13 \\
11 & 9 & 0,9877 & 38 & 304000 & 300257,26 \\
12 & 12 & 0,9781 & 40 & 320000 & 313007,23 \\
13 & 15 & 0,9659 & 41 & 328000 & 316823,67 \\
14 & 18 & 0,9511 & 57 & 456000 & 433681,77 \\
15 & 21 & 0,9336 & 55 & 440000 & 410775,39 \\
& Total & 14,619 & & & 3066346,70 \\
\hline
\end{tabular}

Dari tabel di atas diperoleh panjang fetch efektif untuk arah gelombang timur Desa Rutong adalah:

$$
E_{s f f} \frac{\sum_{n_{t}} \cos \alpha_{t}}{\cos \alpha_{t}}=\frac{3066346_{r} \% 0}{14,619}=209749,344
$$

Tabel 5. Perhitungan Fetch Efektif untuk Desa Rutong Arah Selatan

\begin{tabular}{cccccc}
\hline No & Sudut $\boldsymbol{\alpha}$ & $\mathbf{C o s} \boldsymbol{\alpha}$ & \multicolumn{2}{c}{ Panjang Fetch (Xi) } & Xi Cos $\boldsymbol{\alpha}$ \\
\hline 1 & 21 & 0,9336 & 48 & 384000 & 358494,88 \\
2 & 18 & 0,9511 & 49 & 392000 & 372814,15 \\
3 & 15 & 0,9659 & 55,5 & 444000 & 428871,07 \\
\hline
\end{tabular}

Analisis Perubahan Garis Pantai Desa Rutong Kota Ambon 


\begin{tabular}{cccccc}
\hline 4 & 12 & 0,9781 & 51 & 408000 & 399084,22 \\
5 & 9 & 0,9877 & 38,5 & 308000 & 304208,01 \\
6 & 6 & 0,9945 & 38 & 304000 & 302334,66 \\
7 & 3 & 0,9986 & 50 & 400000 & 399451,81 \\
8 & 0 & 1,0000 & 51 & 408000 & 408000,00 \\
9 & 3 & 0,9986 & 50 & 400000 & 399451,81 \\
10 & 6 & 0,9945 & 50,5 & 404000 & 401786,85 \\
11 & 9 & 0,9877 & 43,5 & 348000 & 343715,54 \\
12 & 12 & 0,9781 & 44,5 & 356000 & 348220,55 \\
13 & 15 & 0,9659 & 19 & 152000 & 146820,73 \\
14 & 18 & 0,9511 & 47 & 376000 & 357597,25 \\
15 & 21 & 0,9336 & 21 & 168000 & 156841,51 \\
& Total & 14,619 & & & 5127693,04 \\
\hline
\end{tabular}

Dari tabel di atas diperoleh panjang fetch efektif untuk arah gelombang selatan Desa Rutong adalah:



Tabel 6. Perhitungan Fetch Efektif untuk Desa Rutong Arah Tenggara

\begin{tabular}{|c|c|c|c|c|c|}
\hline \multirow{2}{*}{ No } & \multirow{2}{*}{ Sudut $\alpha$} & \multirow{2}{*}{$\operatorname{Cos} \alpha$} & \multicolumn{2}{|c|}{ Panjang Fetch (Xi) } & \multirow{2}{*}{$\mathrm{Xi} \operatorname{Cos} \alpha$} \\
\hline & & & $\mathrm{Cm}$ & $\mathbf{M}$ & \\
\hline 1 & 21 & 0,9336 & 20 & 160000 & 149372,87 \\
\hline 2 & 18 & 0,9511 & 19 & 152000 & 144560,59 \\
\hline 3 & 15 & 0,9659 & 18 & 144000 & 139093,32 \\
\hline 4 & 12 & 0,9781 & 90 & 720000 & 704266,27 \\
\hline 5 & 9 & 0,9877 & 85,5 & 684000 & 675578,82 \\
\hline 6 & 6 & 0,9945 & 56 & 448000 & 445545,81 \\
\hline 7 & 3 & 0,9986 & 51 & 408000 & 407440,85 \\
\hline 8 & 0 & 1,0000 & 52 & 416000 & 416000,00 \\
\hline 9 & 3 & 0,9986 & 54 & 432000 & 431407,96 \\
\hline 10 & 6 & 0,9945 & 53 & 424000 & 421677,28 \\
\hline
\end{tabular}




\begin{tabular}{|c|c|c|c|c|c|}
\hline \multirow{2}{*}{ No } & \multirow{2}{*}{ Sudut $\alpha$} & \multirow{2}{*}{$\operatorname{Cos} \alpha$} & \multicolumn{2}{|c|}{ Panjang Fetch (Xi) } & \multirow{2}{*}{$\mathrm{Xi} \operatorname{Cos} \alpha$} \\
\hline & & & $\mathbf{C m}$ & $\mathbf{M}$ & \\
\hline 11 & 9 & 0,9877 & 51 & 408000 & 402976,84 \\
\hline 12 & 12 & 0,9781 & 58 & 464000 & 453860,49 \\
\hline 13 & 15 & 0,9659 & 57 & 456000 & 440462,18 \\
\hline 14 & 18 & 0,9511 & 49,5 & 396000 & 376618,38 \\
\hline 15 & 21 & 0,9336 & 45,5 & 364000 & 339823,28 \\
\hline & Total & 14,619 & & & 5948684,94 \\
\hline
\end{tabular}

Dari tabel di atas diperoleh panjang fetch efektif untuk arah gelombang tenggara Desa Rutong adalah :

$$
F_{s f f} \frac{\sum x_{t} \cos \alpha_{i}}{\operatorname{sQs} \alpha_{t}}=\frac{5948684,94}{14,619}=406911,826 \mathrm{~m}
$$

\subsection{Gelombang pecah}

Untuk menghitung tinggi gelombang signifikan (Hs), periode gelombang (Ts) maka nilai wind stress ffaktor (Ua) dan panjang fetch efektif dimasukan dalam rumus gelombang signifikan. Berikut ini hasil perhitungan tinggi gelombang dan periode gelombang pada lokasi penelitian:

Tabel 7. Hasil perhitungan Gelombang Untuk Arah Timur

\begin{tabular}{cccccccc}
\hline No & $\begin{array}{c}\mathbf{U} \\
(\mathbf{k n o t})\end{array}$ & $\begin{array}{c}\mathbf{U} \\
(\mathbf{m} / \mathbf{d t})\end{array}$ & $\mathbf{U w}$ & $\mathbf{U A}$ & Feff (m) & Hs (m) & Ts (det) \\
\hline 1 & 3 & 1,545 & 2,704 & 2,41311 & 209749,344 & 0,56 & 4,75 \\
2 & 6 & 3,0900 & 4,944 & 5,06961 & 209749,344 & 1,19 & 6,07 \\
3 & 9 & 4,635 & 6,721 & 7,39575 & 209749,344 & 1,73 & 6,88 \\
4 & 12 & 6,180 & 8,034 & 9,21138 & 209749,344 & 2,16 & 7,39 \\
5 & 15 & 7,725 & 9,463 & 11,26629 & 209749,344 & 2,64 & 7,90 \\
6 & 18 & 9,270 & 10,66 & 13,04442 & 209749,344 & 3,05 & 8,29 \\
7 & 21 & 10,82 & 10,9 & 13,44084 & 209749,344 & 3,15 & 8,38 \\
\hline
\end{tabular}

Berdasarkan data fetch efektif di atas maka secara keseluruhan dari ketiga arah angin yang ditinjau dapat terlihat bahwa gelombang yang diakibatkan oleh angin sangat 
dominan adalah arah tenggara dikarenakan panjang fetch pada arah tenggara lebih jauh jika dibandingkan dengan arah timur dan selatan.

Tabel 8. Hasil perhitungan Gelombang Untuk Arah Tenggara

\begin{tabular}{|c|c|c|c|c|c|c|c|}
\hline No & $\begin{array}{c}\mathrm{U} \\
\text { (knot) }\end{array}$ & $\begin{array}{c}\mathrm{U} \\
(\mathrm{m} / \mathbf{d t})\end{array}$ & Uw & UA & Feff (m) & Hs (m) & Ts (det) \\
\hline 1 & 3 & 2 & 2,704 & 2,41311 & 406911,836 & 0,79 & 5,91 \\
\hline 2 & 6 & 3 & 4,944 & 5,06961 & 406911,836 & 1,65 & 7,56 \\
\hline 3 & 9 & 5 & 6,721 & 7,39575 & 406911,836 & 2,41 & 8,56 \\
\hline 4 & 12 & 6 & 8,034 & 9,21138 & 406911,836 & 3,00 & 9,20 \\
\hline 5 & 15 & 8 & 9,463 & 11,26629 & 406911,836 & 3,67 & 9,83 \\
\hline 6 & 18 & 9 & 10,66 & 13,04442 & 406911,836 & 4,25 & 10,32 \\
\hline 7 & 21 & 11 & 10,9 & 13,44084 & 406911,836 & 4,38 & 10,42 \\
\hline
\end{tabular}

Tabel 9. Hasil perhitungan Gelombang Untuk Arah Selatan

\begin{tabular}{cccccccc}
\hline No & $\begin{array}{c}\mathbf{U} \\
(\mathbf{k n o t})\end{array}$ & $\begin{array}{c}\mathbf{U} \\
(\mathbf{m} / \mathbf{d t})\end{array}$ & $\mathbf{U w}$ & $\mathbf{U A}$ & Feff (m) & Hs (m) & Ts (det) \\
\hline 1 & 3 & 1,545 & 2,704 & 2,41311 & 350752,984 & 0,73 & 5,63 \\
2 & 6 & 3,090 & 4,944 & 5,06961 & 350752,984 & 1,53 & 7,19 \\
3 & 9 & 4,635 & 6,721 & 7,39575 & 350752,984 & 2,24 & 8,15 \\
4 & 12 & 6,180 & 8,034 & 9,21138 & 350752,984 & 2,79 & 8,76 \\
5 & 15 & 7,725 & 9,463 & 11,26629 & 350752,984 & 3,41 & 9,36 \\
6 & 18 & 9,270 & 10,66 & 13,04442 & 350752,984 & 3,95 & 9,83 \\
7 & 21 & 10,815 & 10,9 & 13,44084 & 350752,984 & 4,07 & 9,92 \\
\hline
\end{tabular}

\subsection{Refraksi dan Shoalling}

Hasil perhitungan Refraksi gelombang dan tinggi gelombang arah Timur $\left(\phi_{0}=\right.$ $\left.115^{\circ}\right)$, tenggara $\left(\phi_{0}=135^{\circ}\right)$ dan Selatan $\left(\phi_{0}=225^{\circ}\right)$ adalah sebagai berikut :

Tabel 10. Refraksi Gelombang untuk arah Timur

\begin{tabular}{|c|c|c|c|c|c|c|c|c|c|c|c|c|c|c|c|c|c|c|c|c|}
\hline Hs & 1 & 0 & Lo & $C_{0}$ & 0 & $d L$ & L & C & $\mathrm{nj}$ & $\mathrm{j}$ & $\mathrm{kr}$ & no & k & n & $\mathrm{ks}$ & $\mathrm{H}^{\prime} 0$ & $\mathrm{Hb}$ & db & cb & $\mathrm{Lb}$ \\
\hline 05 & 4,75 & 3,0 & & 20 & & & 23,823 & 5,013 & & 158 & 86 & 0,5 & 2637 & 0,8395 & 9389 & 0,61 & 59 & 342 & 874 & 0,005 \\
\hline 1,19 & 607 & , & 57562 & 0,470 & 0,052 & 00062 & 3177 & 5,135 & 0101 &  & 1,035 & 05 & 5 & 0,8961 & 1,0149 & 1,23 & & 1,754 & 1,148 & 0683 \\
\hline 1,7 & 0,8 & 3,0 & & & 0,0 & & 35,075 & 5,100 & 0,430 & 25,499 & 017 & 0,5 & 991 & 0,9153 & 1,0724 & 1,76 & 89 & 334 & 885 & 0,696 \\
\hline 2,16 & 7,39 & 3,0 & & 115 & 0,035 & 0077 & 38 & 5,237 & 0,411 & $27,2,1]$ & 1,012 & 0,5 & 0,1027 & 0,9289 & 1,0993 & 2,18 & 2836 & 2803 & 5,327 & 1070 \\
\hline 2,64 & 7,90 & 3,0 & 97,491 & 337 & 0,031 & 0,0726 & 41,322 & 5,229 & 0,384 & 22,591 & 1,005 & 0,5 & 0,1521 & 0,9368 & 1,1221 & $2,0)$ & 47 & 3,585 & 5,930 & 0,750 \\
\hline 205 & 0 & 3 & na? & in & 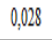 & 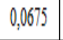 & 416 & 501 & 077 & 2001 & 1002 & 05 & n.41 & neuse & 1.26 & 306 & 3,830 & 2000 & 6,251 & 075 \\
\hline 3,15 & 8,38 & 3,0 & 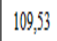 & 13,077 & 0,027 & 6661 & 45,365 & 5,416 & 0,375 & 22,047 & 1,003 & 0,5 & 0,1385 & 0,9468 & 1,1292 & 3,16 & 3,95 & 4,10 & 6,35 & 0,76 \\
\hline
\end{tabular}


Tabel 11. Refraksi Gelombang untuk arah Tenggara

\begin{tabular}{|c|c|c|c|c|c|c|c|c|c|c|c|c|c|c|c|c|c|c|c|c|}
\hline Hs & I & $d$ & Lo & $\mathrm{Co}_{0}$ & $\mathrm{~d}_{0}$ & $d L$ & $\mathrm{~L}$ & C & $\sin j$ & j & $\mathrm{kr}$ & no & k & n & ks & $\mathrm{H}^{\prime} 0$ & Hb & $\mathrm{db}$ & cb & $\mathrm{Lb}$ \\
\hline 0,79 & 5,91 & 3,0 & 54,61 & 9,233 & 0,055 & 0,16825 & 17,83 & 3,015 & 0,231 & 13,350 & 0,717 & 0,5 & 0,352 & 0,759 & 1,420 & 0,56 & 0,959 & 0,221 & 3,005 & 0,508 \\
\hline 1,65 & 7,56 & 3,0 & 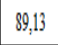 & 11,797 & 0,034 & 0,1833 & 16,37 & 2,166 & 0,130 & 7,461 & 0,710 &,$P$ & 84 & 0,732 & 1,928 & , th & 1,996 & 1,956 & 380 & 0,580 \\
\hline 2,41 & 8,56 & 3,0 & 114,36 & 13,362 & 0,026 & 0,19331 & 15,52 & 1,813 & 0,096 & 5,507 & 0,709 & 0,5 & 0,405 & 0,716 & 2,269 & 1,71 & 2,906 & 2,848 & 5,285 & 0,018 \\
\hline 3,00 & 9,20 & 3,0 & 132,19 & 14,36 & 0,023 & 0,2 & 14,9 & 1,62 & 0,080 & 4,58 & 0,708 & 0,5 & 0,421 & 0,7 & 250 & 2,13 & 2,766 & 2,710 & 5,156 & 0,560 \\
\hline 3,67 & 9,06 & 3,0 & 128,04 & 14,139 & 0,023 & 0,20666 & 14,52 & 1,003 & 0,080 & 4,598 & 0,708 & 0,5 & 0,433 & 0,695 & 2,520 & 2,60 & 3,383 & 3,315 & 5,703 & 0,630 \\
\hline 4,25 & 10,32 & 3,0 & 166,31 & 16,114 & 0,018 & 0,21251 & 14,12 & 1,368 & 0,060 & 3,44 & 0,708 & 0,5 & 0,45 & 0,686 & 2,931 & 3,01 & 3,914 & 3,835 & 6,134 & 0,594 \\
\hline 4,38 & 10,42 & 3,0 & 169,63 & 16,274 & 0,018 & 0,21671 & 13,84 & 1,328 & 0,058 & 3,308 & 0,708 & 0,5 & 0,454 & 0,680 & 3,003 & 3,10 & 4,03 & 3,95 & 6,23 & 0,60 \\
\hline
\end{tabular}

Tabel 12. Refraksi Gelombang untuk arah Selatan

\begin{tabular}{|c|c|c|c|c|c|c|c|c|c|c|c|c|c|c|c|c|c|c|c|c|}
\hline Hs & I & $d$ & Lo & $C_{0}$ & $d \mathbb{L}_{0}$ & $\mathrm{~d} L$ & $\mathrm{~L}$ & C & $\sin j$ & $j$ & $\mathrm{kr}$ & no & $\mathrm{k}$ & II & ks & $\mathrm{H}^{\prime} 0$ & $\mathrm{Hb}$ & db & $c b$ & $\mathrm{Lb}$ \\
\hline 0,367 & 4,49 & 3,0 & 31,43 & 7,005 & 0,095 & 0,1791 & 16,748 & 3,733 & $-0,377$ & $.22,133$ & 0,735 & 0,5 & 0,375 & 0,740 & 1,126 & 0,27 & 0,472 & 0,434 & 2,064 & 0,460 \\
\hline 0,861 & 5,94 & 3,0 & 55,18 & 9,281 & 0,054 & 0,1966 & 15,256 & 2,566 & $-0,196$ & $-11,275$ & 0,714 & 0,5 & 0,412 & 0,710 & 1,596 & 0,61 & 1,045 & 1,003 & 3,137 & 0,528 \\
\hline 1,418 & 7,01 & 3,0 & 76 & 10,942 & 0,039 & 0,2075 & 14,459 & 2,063 & $-0,133$ & $-7,662$ & 0,710 & 0,5 & 0,435 & 0,693 & 1,956 & 1,01 & 1,712 & 1,678 & 4,057 & 0,579 \\
\hline 2,200 & 7,88 & 3,0 & 96,85 & 12,297 & 0,031 & 0,2159 & 13,897 & 1,764 & $-0,101$ & $-5,823$ & 0,709 & 0,5 & 0,452 & 0,681 & 2,262 & 1,43 & 2,434 & 2,385 & 4,837 & 0,614 \\
\hline 2,657 & 8,62 & 3,0 & 116,09 & 13,46 & 0,026 & 0,2226 & 13,478 & 1,56 & $-0,082$ & 4,709 & 0,708 & 0,5 & 0,466 & 0,6 & 2,533 & 1,88 & 2,635 & 2,582 & 5,033 & 0,584 \\
\hline 3,326 & 9,29 & 3,0 & 134,61 & 14,497 & 0,022 & 0,2285 & 13,130 & 1,414 & $-0,069$ & $-3,955$ & 0,708 & 0,5 & 0,479 & 0,663 & 2,780 & 2,35 & 3,061 & 2,999 & 5,424 & 0,584 \\
\hline 4,220 & 9,88 & 3,0 & 152,55 & 15,433 & 0,020 & 0,2336 & 12,844 & 1,299 & $-0,060$ & $.3,413$ & 0,708 & 0,5 & 0,489 & 0,656 & 3,008 & 2,84 & 3,70 & 3,62 & 5,96 & 0,60 \\
\hline
\end{tabular}

Berdasarkan hasil perhitungan maka, analisa refaksi dan tinggi gelombang terbesar untuk setiap arah di sajikan dalam tabel di bawah ini:

Tabel 13. Hasil Analisa Refraksi Gelombang

\begin{tabular}{lccccc}
\hline Arah & $\begin{array}{c}\text { Tinggi gel. } \\
\text { Refraksi } \\
\text { (H'o) }\end{array}$ & $\begin{array}{c}\text { Tinggi gel. } \\
\text { Pecah } \\
\text { (Hb) }\end{array}$ & $\begin{array}{c}\text { Panjang gel. } \\
\text { Pecah } \\
\text { (Lb) }\end{array}$ & $\begin{array}{c}\text { Celerity gel. } \\
\text { Pecah } \\
\text { (Cb) }\end{array}$ & $\begin{array}{c}\text { Kedalaman } \\
\text { gel. Pecah } \\
\text { (db) }\end{array}$ \\
\hline Timur & $3,16 \mathrm{~m}$ & $3,95 \mathrm{~m}$ & $0,76 \mathrm{~m}$ & $6,35 \mathrm{~m} / \mathrm{dt}$ & $4,10 \mathrm{~m}$ \\
Tenggara & $3,10 \mathrm{~m}$ & $4,03 \mathrm{~m}$ & $0,60 \mathrm{~m}$ & $6,23 \mathrm{~m} / \mathrm{dt}$ & $3,95 \mathrm{~m}$ \\
Selatan & $2,84 \mathrm{~m}$ & $3,70 \mathrm{~m}$ & $0,60 \mathrm{~m}$ & $5,96 \mathrm{~m} / \mathrm{dt}$ & $3,62 \mathrm{~m}$ \\
\hline
\end{tabular}




\subsection{Perubahan Garis Pantai}

Tabel 14. Prediksi perubahan garis pantai

\begin{tabular}{|c|c|c|c|c|c|c|c|c|c|c|c|c|c|c|c|}
\hline PIAS & Y-Awal & Y-2019 & $Y-2020$ & Y-2021 & Y-2022 & Y-2023 & Y-2024 & Y-2025 & Y-2026 & Y-2027 & Y-2028 & Y-Akhir & 5 thn & 10 thn & 1 thn \\
\hline 0 & 35,20 & 0,81 & $-1,56$ & $-1,62$ & $-1,69$ & $-1,77$ & $-1,85$ & $-1,94$ & $-2,04$ & $-2,14$ & $-2,24$ & 19,16 & $-5,84$ & $-16,04$ & 0,81 \\
\hline 1 & 37,30 & $-2,42$ & $-0,54$ & $-0,53$ & $-0,52$ & $-0,51$ & $-0,53$ & $-0,60$ & $-0,72$ & $-0,90$ & $-1,12$ & 28,91 & $-4,52$ & $-8,39$ & $-2,42$ \\
\hline 2 & 39,50 & $-2,42$ & $-0,51$ & $-0,51$ & $-0,51$ & $-0,51$ & $-0,51$ & $-0,52$ & $-0,52$ & $-0,52$ & $-0,52$ & 32,44 & $-4,48$ & $-7,06$ & $-2,42$ \\
\hline 3 & 41,70 & $-2,42$ & $-0,51$ & $-0,51$ & $-0,51$ & $-0,51$ & $-0,51$ & $-0,51$ & $-0,51$ & $-0,51$ & $-0,51$ & 34,65 & $-4,48$ & $-7,05$ & $-2,42$ \\
\hline 4 & 43,20 & $-2,43$ & $-0,51$ & $-0,51$ & $-0,51$ & $-0,51$ & $-0,51$ & $-0,51$ & $-0,51$ & $-0,51$ & $-0,51$ & 36,13 & $-4,49$ & $-7,07$ & $-2,43$ \\
\hline 5 & 45,31 & $-2,42$ & $-0,51$ & $-0,51$ & $-0,51$ & $-0,51$ & $-0,51$ & $-0,51$ & $-0,51$ & $-0,51$ & $-0,51$ & 38,26 & $-4,48$ & $-7,05$ & $-2,42$ \\
\hline 6 & 49,50 & $-2,40$ & $-0,57$ & $-0,56$ & $-0,56$ & $-0,56$ & $-0,56$ & $-0,56$ & $-0,55$ & $-0,55$ & $-0,55$ & 42,08 & $-4,65$ & $-7,42$ & $-2,40$ \\
\hline 7 & 51,80 & $-2,42$ & $-0,52$ & $-0,52$ & $-0,52$ & $-0,52$ & $-0,52$ & $-0,52$ & $-0,52$ & $-0,52$ & $-0,52$ & 44,73 & $-4,48$ & $-7,07$ & $-2,42$ \\
\hline 8 & 53,20 & $-2,44$ & $-0,52$ & $-0,52$ & $-0,52$ & $-0,52$ & $-0,52$ & $-0,52$ & $-0,52$ & $-0,52$ & $-0,52$ & 46,13 & $-4,50$ & $-7,07$ & $-2,44$ \\
\hline 9 & 57,60 & $-2,40$ & $-0,58$ & $-0,58$ & $\begin{array}{l}-0,57 \\
\end{array}$ & $-0,57$ & $-0,57$ & $-0,56$ & $-0,56$ & $\begin{array}{ll}-0,56 \\
\end{array}$ & $-0,56$ & 50,10 & $-4,70$ & $-7,50$ & $-2,40$ \\
\hline 10 & 59,00 & $-2,44$ & $-0,52$ & $-0,52$ & $-0,51$ & $-0,51$ & $-0,51$ & $-0,51$ & $-0,51$ & $-0,51$ & $-0,51$ & 51,93 & $-4,50$ & $-7,07$ & $-2,44$ \\
\hline 11 & 61,10 & $-2,42$ & $-0,51$ & $-0,51$ & $-0,51$ & $-0,51$ & $-0,51$ & $-0,51$ & $-0,51$ & $-0,51$ & $-0,51$ & 54,05 & $-4,48$ & $-7,05$ & $-2,42$ \\
\hline 12 & 70,00 & $-2,78$ & $-1,10$ & $-0,99$ & $-0,91$ & $-0,85$ & $-0,80$ & $-0,76$ & $-0,73$ & $-0,71$ & $-0,69$ & 59,67 & $-6,63$ & $-10,33$ & $-2,78$ \\
\hline 13 & 75,90 & $-2,46$ & $-0,74$ & $-0,78$ & $-0,81$ & $-0,82$ & $-0,83$ & $-0,82$ & $-0,82$ & $-0,80$ & $-0,79$ & 66,23 & $-5,60$ & $-9,67$ & $-2,46$ \\
\hline 14 & 79,20 & $-2,40$ & $-0,5$ & $-0,54$ & $-0,5$ & $-0,56$ & $-0,57$ & $-0,59$ & $-0,60$ & $-0,6$ & $-0,63$ & 71,60 & $-4,58$ & $-7,60$ & $-2,40$ \\
\hline 15 & 82,10 & $-2,41$ & $-0,52$ & $-0,52$ & $-0,52$ & $-0,52$ & $-0,52$ & $-0,53$ & $-0,53$ & $-0,53$ & $-0,53$ & 74,97 & $-4,50$ & $-7,13$ & $-2,41$ \\
\hline 16 & 80,20 & $-2,39$ & $-0,54$ & $-0,54$ & $-0,54$ & $-0,54$ & $-0,54$ & $-0,54$ & $-0,54$ & $-0,54$ & $-0,54$ & 72,95 & $-4,55$ & $-7,25$ & $-2,39$ \\
\hline 17 & 84,50 & $-2,40$ & $-0,57$ & $-0,57$ & $-0,57$ & $-0,57$ & $-0,56$ & $-0,56$ & $-0,56$ & $-0,56$ & $-0,56$ & 77,01 & $-4,67$ & $-7,49$ & $-2,40$ \\
\hline 18 & 86,30 & $-2,43$ & $-0,51$ & $-0,51$ & $-0,51$ & $-0,51$ & $-0,51$ & $-0,51$ & $-0,51$ & $-0,51$ & $-0,51$ & 79,25 & $-4,48$ & $-7,05$ & $-2,43$ \\
\hline 19 & 90,50 & $-2,40$ & $-0,57$ & $-0,56$ & $-0,56$ & $-0,56$ & $-0,56$ & $-0,56$ & $-0,55$ & $-0,55$ & $-0,55$ & 83,08 & $-4,65$ & $-7,42$ & $-2,40$ \\
\hline 20 & 93,70 & $-2,40$ & $-0,53$ & $-0,53$ & $-0,53$ & $-0,53$ & $-0,53$ & $-0,53$ & $-0,53$ & $-0,53$ & $-0,53$ & 86,51 & $-4,52$ & $-7,19$ & $-2,40$ \\
\hline 21 & 94,00 & $-2,45$ & $-0,53$ & $-0,53$ & $-0,53$ & $-0,53$ & $-0,53$ & $-0,53$ & $-0,53$ & $-0,53$ & $-0,53$ & 86,82 & $-4,56$ & $-7,18$ & $-2,45$ \\
\hline 22 & 97,00 & $-2,40$ & $-0,53$ & $-0,53$ & $-0,53$ & $-0,53$ & $-0,53$ & $-0,53$ & $-0,53$ & $-0,53$ & $-0,53$ & 89,87 & $-4,51$ & $-7,13$ & $-2,40$ \\
\hline 23 & 99,00 & $-2,42$ & $-0,5$ & $-0,51$ & $-0,5$ & $-0,5$ & $-0,51$ & $-0,5$ & $-0,5$ & $-0,51$ & $-0,51$ & 91,95 & -4, & $-7,05$ & $-2,42$ \\
\hline 24 & 101,10 & $-2,42$ & $-0,5$ & $-0,5$ & -0 , & $-0,5$ & $-0,51$ & -0, & $-0,5$ & -0, & -0, & 94,05 & -4, & $-7,05$ & $-2,42$ \\
\hline 25 & 104,40 & $-2,40$ & $-0,53$ & $-0,53$ & $-0,53$ & $-0,53$ & $-0,53$ & $-0,53$ & $-0,53$ & $-0,53$ & $-0,53$ & 97,23 & $-4,53$ & $-7,17$ & $-2,40$ \\
\hline 26 & 107,80 & $-2,40$ & $-0,53$ & $-0,53$ & $-0,53$ & $-0,53$ & $-0,53$ & $-0,53$ & $-0,53$ & $-0,53$ & $-0,53$ & 100,60 & $-4,54$ & $-7,20$ & $-2,40$ \\
\hline 27 & 113,20 & $-2,43$ & $-0,6$ & $-0,6$ & $-0,6$ & $-0,6$ & $-0,61$ & $-0,6$ & $-0,6$ & -0, & -0, & 105,22 & $-4,4$ & $-7,98$ & $-2,43$ \\
\hline 28 & 114,40 & $-2,44$ & $-0,52$ & $-0,52$ & $-0,5$ & $-0,5$ & $-0,51$ & $-0,5$ & $-0,5$ & -0, & $-0,51$ & 107,33 & $-4,5$ & $-7,07$ & $-2,44$ \\
\hline 29 & 113,90 & $-2,4$ & -0, & -0, & -0 & -0, & -0, & -0, & -0, & -0, & -0, & 106,63 & $-4,4$ & $-7,27$ & $-2,45$ \\
\hline 30 & 115,30 & $-2,4$ & -0, & -0, & -0 , & -0, & -0 & -0, & -0, & -0, & -0, & 108,23 & -4, & $-7,07$ & $-2,44$ \\
\hline 31 & 118,70 & $-2,40$ & $-0,54$ & $-0,53$ & $-0,53$ & $-0,53$ & $-0,53$ & $-0,53$ & $-0,53$ & $-0,53$ & $-0,53$ & 111,50 & $-4,54$ & $-7,20$ & $-2,40$ \\
\hline 32 & 121,10 & $-2,4$ & $-0,5$ & -0, & -0, & -0, & -0, & -0, & -0, & -0, & $-0,5$ & 114,04 & $-4,4$ & $-7,06$ & $-2,41$ \\
\hline 33 & 123,40 & $-2,42$ & $-0,5$ & $-0,52$ & $-0,5$ & $-0,52$ & $-0,52$ & $-0,52$ & $-0,52$ & $-0,5$ & -0, & 116,35 & -4, & $-7,05$ & $-2,42$ \\
\hline 34 & 123,00 & $-2,45$ & $-0,5$ & $-0,53$ & $-0,5$ & $-0,53$ & $-0,53$ & $-0,53$ & $-0,53$ & -0, & $-0,54$ & 115,74 & $-4,5$ & $-7,26$ & $-2,45$ \\
\hline 35 & 125, & -2, & -0, & -0, & -0 & & -0 & -0 & & -0 & -0, & 118,60 & -4, & $-7,10$ & $-2,41$ \\
\hline 36 & 128,10 & $-2,4$ & $-0,5$ & $-0,52$ & -0, & $-0,52$ & $-0,52$ & $-0,5$ & $-0,52$ & -0, & $-0,5$ & 121,04 & $-4,4$ & $-7,06$ & $-2,41$ \\
\hline 37 & 130,50 & $-2,4$ & $-0,5$ & $-0,52$ & $-0,5$ & $-0,5$ & $-0,52$ & $-0,5$ & $-0,5$ & $-0,5$ & -0, & 123,44 & $-4,48$ & $-7,06$ & $-2,41$ \\
\hline 38 & 131,40 & $-2,4$ & -0, & -0, & & & -0, & -0, & & $-0,5$ & -0, & 124 & $-4,5$ & $-7,12$ & $-2,44$ \\
\hline 39 & 129,40 & $-2,3$ & -0, & -0, & -0 , & & -0 & -0, & & -0, & -0, & 122 & -4, & $-7,23$ & $-2,38$ \\
\hline 40 & 132,50 & $-2,40$ & $-0,5$ & $-0,5$ & $-0,5$ & -0, & -0, & $-0,53$ & -0, & -0, & $-0,53$ & 125,35 & $-4,5$ & $-7,15$ & $-2,40$ \\
\hline 41 & 133,0 & $-2,4$ & $-0,5$ & $-0,5$ & -0, & -0, & $-0,5$ & -0, & -0, & $-0,5$ & $-0,52$ & 125 & $-4,5$ & $-7,16$ & $-2,45$ \\
\hline 42 & 135,00 & $-2,42$ & $-0,51$ & $-0,51$ & $-0,51$ & $-0,51$ & $-0,51$ & $-0,51$ & $-0,51$ & $-0,51$ & $-0,51$ & 127,95 & $-4,48$ & $-7,05$ & $-2,42$ \\
\hline 43 & 135,00 & $-2,45$ & $-0,53$ & $-0,53$ & $-0,53$ & $-0,53$ & $-0,53$ & $-0,53$ & $-0,53$ & $-0,53$ & $-0,53$ & 127,78 & $-4,57$ & $-7,22$ & $-2,45$ \\
\hline 44 & 138 & $-2,4$ & $-0,5$ & -0, & -0, & -0, & -0, & -0, & -0, & -0, & -0, & & $-4,51$ & $-7,14$ & $-2,40$ \\
\hline 45 & 137,60 & $-2,45$ & $-0,5$ & $-0,5$ & $-0,5$ & $-0,5$ & $-0,53$ & $-0,53$ & $-0,53$ & $-0,5$ & $-0,53$ & 130,34 & $\begin{array}{l}-4,59 \\
\end{array}$ & $-7,26$ & $-2,45$ \\
\hline 46 & 138,00 & $-2,45$ & $-0,52$ & $-0,52$ & $-0,52$ & $-0,52$ & $-0,52$ & $-0,52$ & $-0,52$ & $-0,52$ & $-0,52$ & 130,84 & $-4,55$ & $-7,16$ & $-2,45$ \\
\hline 47 & 139,00 & $-2,4$ & $-0,5$ & $-0,5$ & $-0,5$ & 8 & -0, & -0, & & 0 & -0 & & $-4,5$ & $-7,10$ & $-2,44$ \\
\hline 48 & 140,00 & $-2,44$ & $-0,52$ & $-0,52$ & $-0,52$ & $-0,52$ & $-0,52$ & $-0,52$ & -0, & $-0,5$ & $-0,52$ & 132,89 & $-4,52$ & $-7,11$ & $-2,44$ \\
\hline 49 & 141,00 & $-2,44$ & $-0,52$ & $-0,52$ & $-0,52$ & $-0,52$ & $-0,52$ & $-0,52$ & $-0,52$ & $-0,52$ & $-0,52$ & 133,89 & $-4,52$ & $-7,11$ & $-2,44$ \\
\hline
\end{tabular}

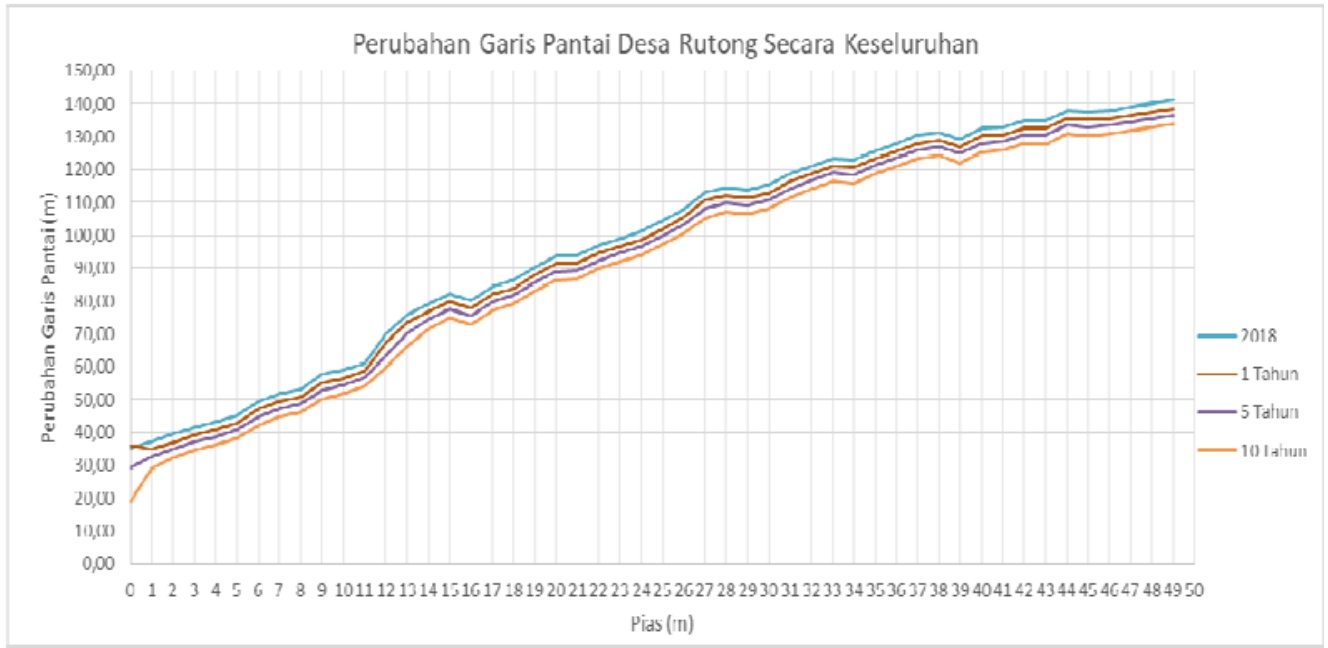

Gambar 10. Grafik Perubahan Garis Pantai Desa Rutong 


\section{KESIMPULAN DAN REKOMENDASI}

\subsection{Kesimpulan}

Berdasarkan hasil dan pembahasan pada penulisan ini maka kesimpulan yang diperoleh adalah sebagai berikut:

1. Tinggi gelombang pecah $(\mathrm{Hb})$ arah timur adalah $3,95 \mathrm{~m}$, panjang gelombang pecah (Lb) adalah 0,76 $\mathrm{m}$ dan kedalaman gelombang pecah (db) sebesar 4,10 m. Untuk arah tenggara $\mathrm{Hb}$ adalah 3,1 m, Lb sebesar 4,03 dan db sebesar 3,95 m. Dan untuk arah selatan $\mathrm{Hb}$ adalah 3,70 m, Lb sebesar 0,60 m dan kedalaman gelombang pecah $(\mathrm{db})$ adalah $3,62 \mathrm{~m}$

2. Garis pantai di Desa Rutong mengalami kemunduran garis pantai (erosi) untuk jangka waktu 5 tahun erosi terbesar terjadi pada pias 12 dengan perubahan sebesar $-6,63 \mathrm{~m}$ dari posisi awal. Dan untuk tahun ke-10 erosi terbesar terjadi pada pias 0 dengan kemunduran sebesar -16, $04 \mathrm{~m}$ dari garis pantai awal. Dan erosi terkecil terjadi pada pias 33 sebesar $-7,05 \mathrm{~m}$.

3. Bangunan Pantai yang digunakan sebagai, alternatif penanggulangan Kemunduran garis pantai Desa Rutong adalah kombinasi antara Revetment dan pelindung kaki.

\subsection{Rekomendasi}

Adapun rekomendasi yang diberikan penulis antara lain :

1. Peneliti selanjutnya sebaiknya dibuat perencanaan bangunan pantai berupa revetment untuk menanggulangi erosi yang terjadi pada lokasi penelitian.

2. Masyarakat sekitar Desa Rutong agar lebih memperhatikan dan memilihara daerah Pantai.

\section{DAFTAR PUSTAKA}

1. Triatmodjo Bambang. (1999). Teknik Pantai, Betta Offset, Yogyakarta.

2. Triatmodjo Bambang. (2011). Perencanaan Bangunan Pantai, Betta Offset, Yogyakarta.

3. Triatmadja Radianta. (2009). Model Matematik Teknik Pantai, Betta Offset, Yogyakarta.

4. Pratikto Widi Agus. Ir. (1997) Perencanaan fasilitas pantai dan Laut, BPFE,Yogyakarta. 
5. Yuwono Nur. (1982). Teknik Pantai, Universitas Gajah Mada, Yogyakarta.

6. Lalenoh leonardo. (2016). Perencanaan Bangunan Pengamanan Pantai Pada Daerah Pantai Mangatasik Kecamatan Tombariri Kabupaten Minahasa. Jurnal Sipil Statk. Vol.4, No.12:795-804.

7. Jasin, MI. (2011). Studi Tingkat Kerusakan Garis Pantai Dan Prioritas Penanganan di SWPP Minahasa. Jurnal Ilmiah MEDIA ENGINEERING. Vol. 1, No. 1: 65-68

8. Oki Setyandito, \& Joko Triyanto. (2007). Analisa Erosi Dan Perubahan Garis Pantai Pada Pantai Pasir Buatan Dan Sekitarnya Di Takisung, Propinsi Kalimantan Selatan. Jurnal Teknik Sipil. Vol. 7, No. 3: 224-235

9. Ratna Parauba. (2016). Analisis Karakteristik Gelombang Pecah Di Pantai niampak Utara. Jurnal Sipil Statik. Vol.4, No. 10: 595-603 